\title{
THE POLITICAL, LEGAL AND MORAL SCOPE \\ OF THE UNIVERSAL DECLARATION OF HUMAN RIGHTS: PENDING ISSUES*
}

\author{
ÁNGELES SOLANES CORELLA ${ }^{1}$
}

\begin{abstract}
With the adoption of the Universal Declaration of Human Rights, a new era began in the recognition and guarantee of human rights in the international area. However, since the moment of its approval, this text has received negative evaluations designed to relegate it to the background. The responses to these criticisms allow us to review their political and legal scope, and put it in value as a reference model in the field of human rights, delving into the pending issues to strengthen it. This is intended, on the seventieth anniversary of the Declaration, to insist that this remains an essential bridge to clarify standards that can serve as a basis for discussion between different cultures and ideologies and, therefore, an instrument that each generation must "reappropriate".
\end{abstract}

Keywords UDHR, political consensus, legal value, moral reference, human dignity, new rights.

Summary: I. A new era of rights; II. The difficult political consensus; III. The legal value of the Declaration today and its expansive effect; IV. A possible model of moral reference in the matter of human rights; V. Pending issues for the strengthening of the Declaration: a future with rights.

\section{A NEW ERA OF RIGHTS}

The Universal Declaration of Human Rights (UDHR) was adopted in New York on December 10th, 1948 by means of Resolution 217 (III) of the General Assembly of the United Nations. The UDHR was created marked by the profound effects of World War II, after which it was clear that the protection of human rights had to be an essential issue in the agenda of the new organization of the international system. The Charter of the United Nations (1945) included references to guarantee human rights, to contribute to social progress and improve standards of living. That is why it is not surprising that the Preamble of the Declaration indicates that "disregard and contempt for human rights have resulted in barbarous acts which have outraged the conscience of mankind" so that the objective must be that this situation does not repeat itself.

From the initial discussions, the Declaration was conceived as an aspiration, as a list of objectives to be achieved by the different States, in line with the Preamble "as a common standard of achievement for which all individuals and nations must strive" to promote "respect for these rights and freedoms" and ensure, "by progressive measures

\footnotetext{
*This article is under the research project "Diversity and conviviality: human rights as a framework for action” (DER2015-65840-R), financed by the Spanish Ministry of Science, Innovation and Universities, and the European Regional Development Fund.

${ }^{1}$ Professor of Philosophy of Law, Universitat de València, Spain (angeles.solanes@uv.es).
} 
of national and international, their universal and effective recognition and observance". Thus began a new era in the recognition and guarantee of human rights in the international area that, at this moment, cannot be considered finished.

At the time of its adoption, the UDHR was a monumental event in international law, subsequently it has also influenced the different regional systems and national legal systems. Although it suffers from deficiencies, it cannot be denied that it was one of the first attempts on human rights to articulate the principles by which societies and States would be governed beyond the strict national sovereignty. In that sense, it is a symbol of the recognition in the international system that pure power was not to be the only consideration for determining how governance was pursued and that individuals and societies were deserving of respect and protection and that international law would take a direct interest in these matters (Burchill and Cavandoli, 2011, 50). It cannot be said that the UDHR has fulfilled all its expectations, although a good part of them, even taking into account that the international system for the promotion and protection of human rights that has evolved from the Declaration has not only had to compete with other priorities in the international system, but also with the always latent reluctance of the States to the intromissions in their sovereignty in the matter of rights and sensitivities of a cultural and ideological nature.

After seventy years of validity of the Declaration, the latter has not been able to overcome two of its most common criticisms. The first consists on considering that this text suffers from a Westernist perspective, or worse imperialist, which is born marked by the will of the victors, as a unique valid model of behavior. Thus, it is emphasized that, at the time of its drafting, the importance of national and regional particularities was not taken into account, nor was there a special sensitivity in the recognition and respect of the different historical, cultural and religious patrimonies. In that sense it can be noted, as Santos $(2004,105)$ does, that there are Western or Western-liberal bias in the Declaration because it was drafted without the participation of the majority of the peoples of the world and prioritized civil and political rights, in such a way that it has been the discourse and practice of human rights of a counterhegemonic nature that have proposed non-Western conceptions of human rights, showing that the central task of an emancipatory policy in this field is to transform the conceptualization and practice of human rights from a globalized localism to a project of cosmopolitan nature.

A careful, up-to-date and dynamic reading of the UDHR does not prevent, in my opinion, overcoming that Western perspective, if we focus on the basic aspects of the Declaration. In fact, the appreciation of a biased nature of this international text, which carries a certain risk of disparagement, has always been latent because, as Eleanor Roosevelt pointed out, the documents that express ideals do not impose any burden except to be known by the people, understood and "lived" (Glendon 2011, 30).

To face this criticism, we must point out the ultimate foundation of the declaration, to its true teleological purpose: the dignity of the person, understood as an ascriptive concept, which prevents the treatment of human beings only as a means, in the line proposed from the Kantian categorical imperative. Thus, as we will see, the 
Declaration is an instrument at the service of that concretion of the ideal of justice, which are human rights conceived from a broad transcultural consensus that is sometimes not very concrete, generic or even diffuse in the effort to bring together wills.

The second criticism refers to the UDHR's legal nature, to the extent that it is not a treaty, therefore it cannot be considered as a legally binding instrument by itself. It is also accused of being a mere rhetoric, even justifying speeches at the service of power, which has nothing to do with the reality of human rights. In that sense, attending to that common ideal to which appeals the Preamble, as has been indicated, there has been more insistence on its moral and political value than its juridical one, considering it, as maintained by Cassese $(1991,51)$, "a simple reciprocal and solemn promise that committed only in the ethical-political level, but did not involve legal obligations for the States”. However, since the creation of the Declaration, voices also accredited, such as Cassin's (1951, 293-294), argued that it constituted an authorized interpretation of the Charter of the United Nations and that it was intended to become part of the general principles of law, so that it could be considered as the reference term to appreciate to what extent the States complied with the obligation of cooperation with the United Nations in the field of human rights. The Charter established that the United Nations and the Member States would take measures for the promotion and protection of human rights, and, as will be analyzed, the Economic and Social Council was responsible for establishing a Commission to address the protection of human rights that was constituted in 1946 to draw up an International Bill of Rights, where the UDHR would be the cornerstone of this process.

The great transformation that the Declaration has experienced since its approval and the possibility of carrying out a broad and up-to-date reading of the context in which it must be applied, makes it possible to affirm, as a good part of the doctrine holds, that it constitutes a powerful instrument and that it creates legal obligations for the Member States of the United Nations.

The responses to these criticisms allow us not only to review the political and legal scope of the Declaration departing from its nature and binding character, but also to value it especially as a reference model in the field of human rights, delving into the pending issues to strengthen it. With this, it is intended to collect, on the seventieth anniversary of the UDHR, the invitation made by Eleanor Roosevelt to learn about this international instrument of reference, so that the Declaration would have greater strength. It is the right moment to insist on its importance, since, as Glendon (2011, 27 and 30) maintains, the tension between the global homogenization of forces and a greater recognition of ethnic differences makes it necessary to clarify standards that can serve as a basis for the debate between different cultures and ideologies. To that end, the Declaration continues to be an essential bridge, because as an international instrument, it is a living and dynamic text that does not end in a single interpretation, it is linked to the context in which it is analyzed and it must be "reappropriated" in each generation. 


\section{THE DIFFICULT POLITICAL CONSENSUS}

The Charter of the United Nations, which was signed in 1945, can be considered the immediate antecedent to the UDHR's adoption, although there are several legal instruments adopted before and after that contribute to explain its ethical, political and legal significance (Carrillo Salcedo, 2001, 57). The Declaration is influenced by what Cassese (1991, 31-35) calls "great texts of the past”, from the Cyrus Cylinder (539 BC), the Magna Carta (1215) or the General Privilege of Aragon (1283), to the English Bill of Rights (1689), the Virginia Declaration of Rights and the Declaration of Independence of the United States (both of 1766) and the French Declaration of the Rights of Man and of the Citizen (1789), to delve into the idea of human dignity (Morsink, 2009).

In accordance with the provisions of the Article 68 of the Charter of the United Nations, the Economic and Social Council created, on February 16th, 1946, the first Commission composed of nine persons individually. This Commission was chaired by Eleanor Roosevelt, which should be valued as an achievement with multiple interpretations, if taken into consideration, also at the historical moment, as she herself would remember, that she was the only woman in the delegation, which would make her feel that an error of hers would be interpreted as a mistake on the part of all women and would reduce the chances of work for them in the future. In fact, her own colleagues from the US delegation confessed that they did all that was possible for the president to keep her out of it (Glendon 2011, 69).

This nuclear commission recommended the preparation of a draft declaration of rights and the designation of a larger and more plural group. Thus, by the Resolution 9 (II) of June 21st, 1946, of the Economic and Social Council, it was decided that the Human Rights Commission should be composed of 18 state representatives, as a subsidiary body of the Economic and Social Council (now replaced by the Human Rights Council, as a subsidiary organ of the General Assembly). This option responded, to a large extent, to the reluctance on the part of some States in relation to the establishment of independent bodies with jurisdiction over human rights. As soon as the Commission began to work, the first difficulties arose, showing the sensitivity of the topics that were addressed, which were saved by expanding the group and creating a drafting committee that would take up the drafts and existing proposals and would be in charge of sending the project to the Commission (Pons Rafols, 1998, 33).

The Commission assumed the articulation of a complex process, marked by the ideological and political conflict between different States, which proceeded in different stages and proposals, from the Commission's first session to the presentation of the declaration to the plenary of the General Assembly. From the beginning, several difficulties were raised, among them, as the first question, the question of whether a non-binding declaration of rights would be drawn up, along the lines proposed by the United States and the Soviet Union, or a binding treaty for States as proposed by the United Kingdom, Belgium, Australia and the Philippines. Finally, it was decided to work on a triple objective and jointly draw up a declaration, a human rights treaty and a 
series of measures for its implementation, although the most intense and fruitful work was carried out on the text of the Declaration (Del Toro Huerta, 2012, 50).

Despite the problems that it had to face, the UDHR constituted a kind of balance and political consensus among the different positions that existed in the international community around the difficult issue of human rights. At the request of Poland, it was decided to vote separately on each paragraph of the Preamble and the different articles of the project. The second, third, fourth, fifth, sixth and seventh paragraphs of the "Preamble" and articles 3 to 12, 14 to 17, 20 to 25, 27, 29 and 30 were adopted unanimously, while the final vote on the whole of the Declaration obtained 48 votes in favor, none against, and eight abstentions (Saudi Arabia, Belarus, Czechoslovakia, Poland, Yugoslavia, Ukraine, Soviet Union and South African Union), with the absence of two of the state representatives (Honduras and Yemen) in the moment of the vote. The abstention of Saudi Arabia is considered especially significant because it expresses the reservations to the Declaration dictated by the Muslim cultural tradition in matters of religion and family life that have continued to be maintained. In any case, those who opposed the approval of the Declaration opted to abstain without tarnishing a large majority that did not receive direct opposition (Pons Rafols, 1998, 40-41).

The reasons why States abstained from voting were diverse. In the case of the South African Union, it refused to include social rights and limited the scope of nondiscrimination principle in defense of the apartheid system; Saudi Arabia, opposed to recognize religious freedom and equality between men and women, regarding the right to marriage; and the Soviet bloc, composed of Belarus, Czechoslovakia, Poland, Yugoslavia, Ukraine and the Soviet Union, opposed ideological questions to the incorporation of certain rights, in accordance with the principle of non-intervention, for not taking into account the sovereign rights of the States, the principle of selfdetermination of peoples and the duties of the individual before the State, highlighting the lack of mechanisms to implement the rights recognized in the Declaration (Morsink, 1999, 21-28).

Out of the eight abstentions, today seven can be considered widely surpassed after the end of the Cold War in 1989, which facilitated the adhesion of the States belonging to the at the time socialist bloc to the values represented in it and the end of the apartheid regime in Southern Africa (Villán Durán, 2018, 114).

As Glendon (2011, 28-29) recalls, the texts proclaiming that all human beings are born free and equal and that governments are responsible for protecting these freedoms, elaborated the modern language of law that was basically branched into two discourses: the European and the Anglo-American. The first, under the influence of authors such as Rousseau, was oriented towards freedom and fraternity, considering the State as the guarantor of rights and leveling the latter with duties. In the second, the Anglo-American language on law focused on freedom and individual initiative, with a marked distrust towards the government. When the Latin American countries became independent in the 19th century, these perspectives were mixed. In addition, states such as the Soviet Union adopted a different perspective prioritizing equality over freedom. 
These different approaches had to be synthesized to make it possible for a Declaration with the pretension of being "universal". For this purpose, it was based on such basic principles that no State dared to openly discredit them, which implies a strength and at the same time a weakness of the Declaration that did not prevent it from displacing the documents that preceded it to become the main model of the current legal instruments.

The Declaration establishes the bases for the protection of human rights and is structured, in the words of Cassin (1951, 267), in what he calls the "four columns" and the facade, which make up the "portico" of the Declaration. The first column is formed by the rights and freedoms of personal order (articles 3 to 11); the second, by the rights of the individual in relation to the groups of which he is a part (articles 12 to 17); the third is constituted by political rights (articles 18-21); and the last refers to economic, social and cultural rights (articles 22 to 27). On these four columns there is a frontispiece, the articles 28 to 30, which indicate the links between the individual and the society of which they are a part.

After the Declaration's adoption, the General Assembly recommended that the States published the text and arranged for it to be distributed and exposed to make it known. Until the approval of the International Covenants on Human Rights of 1966 (International Covenant on Civil and Political Rights, ICCPR and International Covenant on Economic, Social and Cultural Rights, ICESCR), the UDHR was the only document of international reference to face the challenges in the area of human rights. Subsequently, international human rights law was developed, consolidating this process started with the Declaration that can be considered as humanization and internationalization of international law, affecting those that can be considered as the three aspects of international protection of the rights of human beings: human rights, humanitarian law and refugee law (Cançado Trindade, Peytrignet and Ruiz de Santiago, 2003).

The first step that the Declaration took has been completed with a thematic specialization supported by the Human Rights Commission, the Economic and Social Council and the General Assembly, and by proposals at the regional level and also coming from other international organizations such as the ILO or the UNESCO. This specialization process has tried to address specific situations or respond to certain groups, following the guidelines of the UDHR and the international human rights pacts, beginning with a text that generally includes certain rights and subsequently a treaty with a binding nature for the States Parties, with monitoring and implementation mechanisms (Del Toro Huerta, 2012, 56).

The reticence of a political nature that had already been revealed at the time of the vote on the Declaration, linked to religious issues, has persisted. Thus, the States of the Organization of the Islamic Conference (later called the Organization for Islamic Cooperation) adopted the Cairo Declaration on Human Rights in Islam, on August 5th, 1990. In 1997, this group of States maintained that the recognition and total respect for the world's main legal systems, including Islamic jurisprudence, is essential for the promotion of universality postulated by the UDHR; it advocated the codification of the 
Islamic norms and principles included in the Cairo Declaration in a universally recognized Islamic human rights instrument and promoted the adoption of common positions in international human rights forums, in defense of the values embodied by the Islamic sharia (Villan Durán, 1998, 80). In the subsequent summits of the Organization for Islamic Cooperation, as the one held in 2016 (Istanbul) and the one announced for 2019, the question of the protection and guarantee of rights is directly related to issues such as security and terrorism.

It has never been easy to reconcile the universality of human rights that the Declaration proclaims with the aspects that are presented as difficult cultural particularisms, which question the general standards of protection, that is precisely the limit for the acceptance of these specialties. Precisely in the establishment of given limits that respect the principles established in the UDHR in the international scope can be appreciated, as well, the level of democratic institutions, since, as Beetham (1999, 24) states "it is only by grasping the underlying principles involved that we are able to assess how far a given institution is democratic in practice, and what else might be required to make it so".

The high level of politicization, to which the Declaration was submitted, continues to be present in many aspects related to the recognition, guarantee and protection of human rights. As Villán Durán $(2018,115)$ points out, that strong political tendency and the absolute majority of the African and Asian States within the Human Rights Council (with a total of 26 votes out of 47), can make us fear for the future of the valuable special procedures system. In this regard, the Council is increasingly hostile to geographical mandates. States interested in the study of the situation of human rights in a country in difficulty prefer it to be carried out by the High Commissioner because it is not an independent expert, but a senior official of the Organization, or simply that no such investigation is carried out.

Certainly, it is possible that the political and moral importance of the Declaration from the outset would even surpass its specific legal significance. As Von Bernstorff (2008) recalls, in the 1980s, the Declaration embodied the hope for a new era of human rights protection after the end of the Cold War, while during the 1990s a new defense of the Declaration's universal character was observed, also examining its institutional limitations. In general, the UDHR can be considered as a synonym for the importance of individual rights in international law, in such a way that, faced with a sense of crisis due to institutional blockages, it receives, again, an increasing attention. Indeed, the Declaration can be seen as symbolizing unity in an increasingly fragmented and controversial institutional and political environment for the international protection of human rights.

In addition, the human rights recognized by the Declaration can be seen from the perspective of Habermas $(2010,118)$ as a "realistic utopia" to the extent that they cement the ideal objective of a just society in the constitutional states, yet they introduce certain tension. Thus, the human rights policy of the United Nations shows the contradiction between the expansion of the rhetoric of human rights and its abuse as an 
instrument of legitimation for the usual politics of power. This is why it is essential to insist on the role that the United Nations' system must play, through the progressive international codification in so far as it allows, to specify the obligations of the States themselves, and also as a way of measuring the progress made by the States themselves within the field of human rights.

This political dimension is undoubtedly essential in the field of human rights, as has already been noted in the studies prior to the approval of the UDHR. In this sense, authors such as Baynes (2009, 7) insist on their eminently political conception because they are conceived as rights within the political community, affirming "according to some theorists, human rights are to be viewed as part of a 'realistic utopia', according to others as constraints obligating any coercive social institution, and others still as basic conditions for membership in any political society. I refer to each of these approaches as political", which, in my opinion, is not exclusive, but rather complementary of its legal and moral dimension.

\section{THE LEGAL VALUE OF THE DECLARATION TODAY AND ITS EXPANSIVE} EFFECT

The repeated discussion about the Declaration's legal value stems from its nature and its questioning binding character. Regarding its nature, the fact that it is a resolution does not necessarily mean that it does not currently have a binding value. Indeed, in the practice of the United Nations "a declaration is a formal and solemn instrument that is used in very special cases, in matters of great and real importance and when maximum observance is expected from the largest number of States possible (...) principles are formulated that are of great importance and lasting value, as in the case of the Declaration of Human Rights" (Memorandum of the Office of Legal Affairs of the UN Secretariat, Doc. E / CN. 4 / L.610).

Already in the early years of the Declaration, Lauterpacht (1950: 150) noted that "it would be contrary both to these requirements (of good faith and of decency) and to the principle of effectiveness if the repeated and solemn provisions of the Charter in the matter of human rights and fundamental freedoms, coupled with the clear legal obligation to promote respect for them by joint and separate action, were interpreted as devoid of the obligation to respect them".

It is true that the resolutions adopted by the General Assembly of the United Nations do not have a strong legislative character a priori, which means that they are not adopted as binding instruments and, in that sense, they lack binding force. However, this does not mean that it does not have legal effects linked to its material importance, its evolutionary interpretation, its progressive development, and the reference to programmatic principles that end up becoming a reference of the evolution of general international law in such a way that crosses the field of soft law to reach hard law.

In general, the legal value of a Declaration is conditioned by the intention to enunciate legal principles, the majority by which it has been adopted, its content, and 
the subsequent practice of the States. The UDHR has, initially since its adoption, two legal effects linked to the duties established in the Charter of the United Nations in the field of human rights. On the one hand, the formation of a principle of international law consisting of the general obligation of States to respect and protect the human rights of individuals subject to their jurisdiction; and on the other hand, the restriction of state sovereignty in accordance with the principle of respect and protection of such rights (Carrillo Salcedo, 2001, 57).

The legal value of the Declaration can be explained with three theories (Oraá, 1999, 185) that are not necessarily mutually exclusive. A first theory holds that the UDHR can be considered as an authorized and authentic interpretation of the Charter of the United Nations in the field of human rights. This interpretation is reinforced by the fact that the various organs of the United Nations constantly appeal to it when they apply the clauses of the Charter, for example, the General Assembly in several of its resolutions, the Commission on Human Rights and the Subcommittee, and the special rapporteurs, among others. In reference to the Declaration, in the key of authority and referent, the jurisprudence of the International Court of Justice of The Hague is also situated (from famous cases such as Barcelona Traction).

From a second perspective, it can be considered that States have incorporated many of the clauses of the UDHR in their domestic legislation and cite it in a continuous manner. This has generated a rule of customary law that does not affect all articles, but a significant part of them. It could even be considered as a rule of ius cogens or peremptory norm of general international law (Lepard, 2010, 318) according to what is established in article 53 of the Vienna Convention on the Law of Treaties. According to what is established in said precept, it could be considered as "a norm accepted and recognized by the international community of States as a whole as a norm that does not admit agreement to the contrary and that can only be modified by a subsequent norm of general international law that has the same character".

In the relation between treaties and custom, applied to the Declarations of the General Assembly proposed by Jiménez de Aréchaga (1980, 19-42), three types of effects can be distinguished: the codifier, insofar as the Declaration could be considered as the compilation of pre-existing standards; the crystallizer, so that the Declaration would collect in writing a custom that was being formed and, in doing so, it would be crystallized into a customary norm; and, finally, the generator, which would allow the Declaration to be considered as a new norm that constitutes the starting point of a subsequent practice of the States, making it become a rule of customary law.

As maintains a part of the doctrine (Oraá, 1999, 188 and Del Toro Huerta, 2012, 71) it is appropriate to consider that, rather than having an encoder or crystallizer preexisting rights effect or being in statu nascendi (since the Charter does not contain any list of rights), the Declaration can be conceived as a document generating legal norms of lege ferenda. In this sense, since it is the first international document of universal and general character on human rights, it is sought that it undoubtedly contributes to its 
internationalization, since, up to now, said matter belonged to the States' internal jurisdiction.

The subsequent practices of both the States and the organs of the international community in relation to the Declaration meet the requirements so that it can be considered as a customary norm, insofar as both the material or objective element regarding the subsequent practice, repeated, constant and uniform, as the formal or subjective element as regards opinio iuris. In this sense, by placing the Charter and the Declaration on the same level, the conviction of the States regarding the mandatory nature of this is evident. To this is added the fact that many of the countries have directly or indirectly taken the Declaration as a model or reference in their constitutions (especially in the countries that achieved their independence after the 1950s), laws and policies in defense of the human rights. Likewise, the different final documents of relevant conferences, such as the Proclamation of Tehran (final act of the International Conference on Human Rights, Tehran April 22 to May 13, 1968, Document NCONF.32 / 11) and the Vienna Declaration (World Conference on Human Rights in Vienna on June 25, 1993, Document A/CONF.157/24), among others, insist on adhering to and acting in accordance with the Charter and the Declaration.

A third possibility would be to consider the Declaration as general principles of law in such a way that they would be considered as a source of international law according to article 38.1.c of the Statute of the International Court of Justice, which would not allow its normative character to be questioned, along the lines that was already noted that were held, for example, by Cassin.

Whichever interpretation is chosen, all of them lead to highlight the general consensus on the part of States about the mandatory nature of the UDHR. There is, however, an open debate that not all articles of the Declaration are equally binding for all States, as a consequence of the general acceptance of the Declaration. This debate connects with the differentiation established in the Pacts of 1966 and the positions that consider that the obligations that generate, on the one hand, civil and political rights, and economic, social and cultural rights on the other, are different, instead of understanding that human rights are universal, indivisible and interdependent. Alston $(1990,1)$ affirms that the Declaration has a "revolutionary content", precisely because it includes economic and social rights as part of the basic rights, considering them indivisible to the rest of human rights, therefore setting an important precedent.

The two international conferences on human rights already mentioned insisted on relevant issues, such as the nature and normative scope of the Universal Declaration, with special mention to the interdependence of rights as well as their universality. Indeed, in the first of them, the Proclamation of Teheran was approved, and in its second paragraph it was affirmed that the UDHR "states a common understanding of the peoples of the world concerning the inalienable and inviolable rights of all members of the human family and constitutes an obligation for the members of the international community". In the same line, in the second conference the Vienna Declaration and Programme of Action were approved, which emphasizes in its fifth paragraph that "all 
human rights are universal, indivisible and interdependent and interrelated". This reaffirms the questionable indivisibility between political, civil, cultural, economic and social human rights, considering them as a set that must be promoted and protected. Both conferences served to reaffirm the ideas of universality, indivisibility and interdependence of human rights that have been subsequently confirmed in multiple international provisions. However, until 2008, the General Assembly did not transfer the Vienna Declaration to positive law through the adoption of the Optional Protocol to the ICESCR.

As Villán Durán $(2018,116)$ recalls, said Protocol constituted a historic milestone in the real equation of all human rights, since it recognized the justiciability of economic, social and cultural rights at the international level, by enabling the DESC Committee to receive individual complaints for alleged violations of any of the rights enshrined in ICESCR. The ratification of the Protocol as affirmed by Añón $(2010,41)$ can be interpreted as a way to assume, on the part of the legislator, new obligations in relation to social rights and a gesture of recognition of their relevance as human rights. In the words of the aforementioned author "it is a feasible legal perspective that involves recomposing the principles of the social and democratic State of law and the institutional role of legal operators linked in their daily activities to the purposes of this model of State".

The Declaration, therefore, has been a decisive text for the guarantee of human rights insofar as it was elaborated through a negotiation that implies a broad, although not unanimous, consensus on the fundamental nature of its content and has allowed the promotion of instruments later, strengthening its binding dimension. However, the pending issue of human rights today is not so much to proclaim them as it is to protect them, since it is obvious that the more respected the Declaration, the greater its degree of effectiveness and legal influence. In any case, among the objectives of the Declaration, both in its origins and that persist today, there is not only the intention to create instruments of jurisdictional protection, but rather the will to express those rights inherent to the dignity of the person, since, as will be analyzed below, it also serves as a standard and valuation fee.

Beyond the legal instruments, and the development thereof, which have emerged from the basis of the Declaration, the latter has an expansive effect that has to do with the different programs that are developed from the United Nations and with the creation of a jurisdictional mechanism. Both initiatives connect with the Article 28 of the Declaration when it states that "everyone is entitled to a social and international order in which the rights and freedoms set forth in this Declaration cannot be fully realized".

With regard to the first issue, both the Charter of the United Nations and the Declaration, as noted, have already shown the importance of the promotion and internationalization of human rights. This has also been transferred to the strategies of cooperation and international development as an indispensable estimation for the construction of peace at a global level. 
On the basis of the aforementioned Article 28, the General Assembly of the United Nations proclaimed in 1986 the right to development as an "inalienable human right by virtue of which every human person and all peoples are entitled to participate in, contribute to, and enjoy economic, social, cultural and political development, in which all human rights and fundamental freedoms can be fully realized" (Declaration on the right to development, resolution 41/128, of December 4, 1986). Thereon, within the United Nations Development Programme, different initiatives have been finalized. As Verdiales López $(2018,77)$ recalls, with the creation of the Millennium Development Goals (MDGs), the possibility of incorporating human rights into each of their strategies was contemplated, even though it was not really achieved that human rights would have a relevant role in the development of said Objectives. The redefinition and expansion of these is proposed through the Sustainable Development Goals, which insist on the importance of the central role of human rights to ensure respect for human dignity and international justice. The 2030 Agenda for Sustainable Development, the basis of the Objectives, departs from the "leaving no one behind" claim and reaffirms the importance of human rights and the responsibility of States to respect, protect and promote human rights and fundamental freedoms of all people without any distinction, in accordance with the Charter.

In the same line as article 28 in relation to the full effectiveness of rights, the international legal order includes specific conventional instruments related to the protection of rights and binding for States parties, among them the Statute of Rome (1998) which established the International Criminal Court. As Herrera Carbuccia (2018, 542-546) points out, the legal value of the Universal Declaration of Human Rights in international standards on human rights has been and continues to be essential in terms of the administration of justice. It is fundamental to point out the role of the International Criminal Court in the application and interpretation of international human rights norms and resolutions adopted by the General Assembly of the United Nations. The Court is the first permanent international criminal court with jurisdiction over the most serious crimes related to the international community. It is a reminder for the States to prevent and stop armed conflicts, contributing to the prevention of international crimes, to international peace and to the protection of the fundamental values of human dignity and life. As stated in the preamble to the Rome Statute, today more than ever, the recognition and effective protection of the rights enunciated in the Universal Declaration of Human Rights are of vital importance in international law, to guarantee respect for due process and an independent and impartial administration of justice that allows creating a world in peace, security and well-being.

\section{A POSSIBLE MODEL OF MORAL REFERENCE IN THE MATTER OF HUMAN RIGHTS}

As has been stated, the Declaration is the symbolically most relevant instrument in the world on human rights. Given its universal vocation and its innovative nature at the time it was drafted, it constitutes a symbol of a protest against infamy, barbarism and any form of collective or individual dehumanization. The Declaration also 
symbolizes a proclamation in favor of each person's dignity, a tool to stimulate the conscience of humanity, motivate protest and social resistance, within the very limits, principles and values that define human rights (Del Toro Huerta, 97-98).

Moreover, the Declaration incorporated, within the very idea of universality, the existence of a heritage and common interest of humanity. As Cançado Trindade points out (2010, 349), conceptions of the common heritage and of common interest of humanity embody the universal solidarity and social responsibility that emanate from human consciousness (not the will of States), and reflect basic values of the international community in a way that allow it to be strengthened in the face of a fragmented vision. Thus, it is possible "to face the new global challenges to the international community as a whole, and indeed to all humankind, and to provide adequate and satisfactory responses to them, which the systems of positive law by themselves simply cannot do".

The main features of human rights that, as has been pointed out, are identified in the Universal Declaration, such as universality, interdependence and indivisibility, make it a living and symbolically relevant instrument, but its fundamental moral scope lies in the idea of human dignity; these traits emerge from it.

In the first place, as regards the idea of dignity, it is present in both the Charter and the Declaration. Dignity is mentioned at the beginning of the UN Charter: "we the peoples of the United Nations determined to reaffirm faith in fundamental human rights, in the dignity and worth of the human person, in the equal rights of men and women and of nations large and small...”. The article 1 of the Declaration provides: "all human beings are born free and equal in dignity and rights". In other human rights instruments, as are the aforementioned 1966 Pacts, the Convention on the Elimination of Discrimination Against Women, the Convention on the Rights of the Child and the Vienna Declaration and Programme of Action, the word "dignity" is connected with equality and the idea that human dignity, which belongs to everyone equally, is the source of all rights.

As Habermas (2010, 108 and 111) rightly states, human dignity is not a qualifying term adopted by the Declaration, but the moral source from which the contents of all rights are nourished. From the very beginning, there has existed, albeit implicitly, a close conceptual relationship between both notions. This author is right when he highlights the catalytic role played by the concept of dignity in the composition of human rights based on rational morality and in the form of subjective rights. In my opinion, Habermas' reference to the notion of human dignity is fully evidenced in the Declaration, thus affirming that human dignity allows the equal universal content of morality to be imported into the right, is, therefore, the conceptual hinge that relates the moral of equal respect to each subject and the positive democratic right.

Dignity with this moral basis has also played a fundamental political role. Since the adoption of the Declaration itself, as McCrudden (2008, 722-724) points out, this concept has allowed different cultures, with very different conceptions of the State, 
different points of view on the foundation of human rights and diverse ethical and moral perspectives have overcome their ideological differences, focusing on the specific. In that sense, he maintains, however, that "everyone could agree that human dignity was central, but not why or how". The concept of dignity can be questioned from different interpretations, but if we look at it as the moral foundation on which the UDHR is based, we should refer to a basic minimum content of the meaning of human dignity. In the words of said author: "a basic minimum content of the meaning of human dignity can be discerned: that each human being possesses an intrinsic worth that should be respected, that some forms of conduct are inconsistent with respect for this intrinsic worth, and that the state exists for the individual not vice versa. The fault lines lie in disagreement on what that intrinsic worth consists in, what forms of treatment are inconsistent with that worth, and what the implications are for the role of the state".

Certainly, there was no need for a more specific common theory, which would exceed that minimum basic content, for the political acceptance of the Charter and the Declaration, not even for the acceptance of subsequent texts on human rights at the international, regional and national levels. Moreover, as was seen when analyzing the political-historical framework in which the Declaration emerged, possibly the attempt to generate a greater consensus could have produced counterproductive results. That minimum character, as McCrudden points out, does not facilitate judicial interpretation of the specific rights that were promulgated, but facilitates substantive meanings, namely, "providing a language in which judges can appear to justify how they deal with issues such as the weight of rights, the domestication and contextualization of rights, and the generation of new or more extensive rights". It is precisely in the development of this function that the UDHR and the set of human rights texts that have developed it can have a relevance in the judicial field that is conjugated with the role that it played at the time of approval in the philosophical, political and legal debate.

As Carozza (2008, 937) also recognizes, the different articles of the Declaration do not provide the specificity necessary to make difficult decisions about how to balance, let's say the rights to which it refers, in such a way that, in any case, the requirement to specify the content of human dignity does not eliminate the need for a judicial interpretation that goes beyond the minimum core of the concepts. As correctly, in my opinion, this author recalls, and in the face of the criticism raised by McCrudden, even if there was no international agreement on some aspect of the minimum requirements of human dignity, there may be good reasons to affirm its validity, the same way that the mere existence of an international consensus on human dignity, per se, is not enough. From my point of view, the essential question to admit that human dignity is that moral source on which rights are nurtured and in that sense the foundation of the Declaration, is to take into consideration that the idea of dignity makes reference, as both authors recognize, to "the ontological claim that each human being has inherent worth as an individual person" in such a way that, on a moral plane, dignity exists independently of a consensus on its meaning and its content.

Regarding the second relevant issue about the moral dimension of the Declaration, the debate on the scope and the claim of human rights' universality in it 
was already put into question at the time of its drafting and marked some of the abstentions as has been pointed. Today, the universality of human rights continues to be questioned from the ideological and cultural dimensions that stress its implementation, making its full validity difficult, either due to restrictions imposed under the protection of some cultural relativisms or because of false universalisms. The debate between relativism and universalism is very broad and can be used to question several rights. In summary, it can be located at three different levels (Del Toro Huerta, 2012, 100): from the interstate perspective (for example, the positions of some Islamic governments against Western governments); the intrastate (with respect to the claims of minority groups or indigenous or tribal peoples within the state sphere), or the intrasocietal (from the perspective of gender, or the demands of the community of transgender, lesbian, gay and bisexual people who question conceptions within of the same culture or society). This debate is interesting as Benhabib (2011, 57-77) masterfully exposes different types of universalism: essentialist universalism, justificatory universalism, moral universalism, and juridical universalism, to be able to bet on a cosmopolitan project that allows to go beyond the current philosophical universalism.

Universality as a feature of the concept of human rights, along the lines proposed by the Declaration, implies both universality in the holders of the rights and in the subjects bound by them. This is a direct consequence of the Kantian requirement of the moral imperatives' universality, but one that transcends this scope with positivity, internationalization and the specification of rights.

In this sense, it is important to remember, as pointed out by Peces-Barba (1994, 614-615) that the universality of rights can be approached from three perspectives: logical, temporal and spatial. In the first case, reference is made to "an ownership of the rights that are ascribed to all human beings. Its features are rationality and abstraction, congruent with that ownership of all men", in a current language, of all people. Temporal universality would imply that rights "have a rational and abstract character regardless of time and valid for any moment in history". Finally, the spatial field refers to "the extension of the culture of human rights to all political societies without exception".

It is precisely this first meaning of universality that allows us to situate ourselves in the realm of morality. As Ansuátegui (1999, 214-215) maintains, in this dimension, the strong symbolic burden of the Declaration could be contrasted and it would acquire a special meaning, the very Declaration and the universality of the rights that it consecrates, provided that it is understood that this universality refers to the framework of moral discourse, as what, in my opinion, can be considered a moral reference that influences other international documents, previously mentioned. On the other hand, in relation to the Law, said universality would be a tendency, understood as an aspiration. Therefore, the universality of human rights is not a matter of fact, but a claim referring to the "universalizable" nature of rights, or, the same way: the aspiration to formulate them in such a way that they are susceptible to acceptance which, in turn, can be admitted as universal. We situate ourselves, therefore, within the framework of a prescriptive and non-descriptive discourse in relation to the universality of rights. 
Universality would be a point of arrival, a goal to reach. This approach is fully compatible with what was expressly stated in the preamble of the Declaration and with its spirit, being consistent with the initial efforts to obtain its approval.

In addition, it is important to keep the role of human dignity in mind, regarding the change of perspective from moral duties to legal rights and also in the promotion of that trending universality. As Habermas $(2010,113)$ points out, the modern theories of rational morality and rational law rest on the fundamental concept of the individual autonomy and on the principle of equal respect for all. This common base is fundamental but it cannot be forgotten that, while morality imposes duties that cover all spheres of action, modern law creates spaces of freedom for private arbitration and the development of individual life, not duties but subjective rights, the ones that form the basis for the construction of the legal system. In the Declaration both approaches find their place.

On the other hand, the universality proposed by the UDHR regarding human rights is neither homogenization nor globalization. In the first place, it is not homogenization because it cannot be conceived as the imposition of a majority culture or the lack of respect for minorities, it cannot be the expression of the rule of the majority that can be imposed by the tyranny of the majority. It is in this sense that it can be affirmed that the democratic system has, as its basic premise, respect for human dignity and, along with it, the universality of rights. That is why the UDHR is considered a revolutionary instrument within the framework of international law to the extent that it represents a first effort to restrict the action of governments to promote and protect human rights over state interests. In the same vein, an international law of democracy in the post-Cold War period has been developed that has also determined the nature of international law and relations. In both cases, the objective is none other than "to promote social progress and better standards of life in larger freedom, ideas and practices that are central to the appropriate understanding of democracy" (Burchill and Cavandoli, 2011, 46).

In addition, universality, as conceived by the Declaration, is not compatible with globalization. As De Lucas $(2008,57)$ rightly explains, the hegemony of financial globalization and the absence of control favor the nexus between globalization and social exclusion, which is the negative result of globalization for most of the human beings that do not belong to the reduced group of process agents, of those integrated in globalization. Moving forward in legal and political globalization is, therefore, a necessity if we want to avoid the most devastating effects of the neoliberal ideology professed by the dogma of deregulation. Faced with the exclusive financial globalization, incompatible with universality, a globalization that demands progress towards the ideal of cosmopolitan democracy is urgent; and at the same time a legal globalization, in particular, of justice and human rights.

From this other conception of globalization, still conceived as an ideal, the Declaration can continue to be the engine to invigorate the universalization of human rights and to reinforce them. 


\section{Pending issues for the StREnghtening of THE Declaration: A FUTURE WITH RIGHTS}

The UDHR, in addition to supposing a radical turn for the conception and evolution of the human rights at international level, today continues being just as significant, or more, politically, legally and morally than when it was approved, even though with all the efforts made also by the instruments that make up international human rights law, there are still violations. Securing and guaranteeing rights continues to be a work in progress in the three dimensions analyzed.

From the political point of view, just like at the time of the Declaration, the role of the States in the international and national dimension, ad intra and ad extra, remains essential, even more so with the impact of globalization. As Brown (2016, 72-73) recalls, the States have assumed their role as guarantors of the rights of everyone: civil, political, social, economic and cultural, fulfilling their obligations. The special position of the countries is not only a matter of effectiveness and control, but also a form of legitimacy that distinguishes them from other entities and agencies. The UDHR and the conventions aim to impose conditions based on human rights to this legitimacy, in this sense the human rights regime initiated by the UDHR was conceived as a basis, not only for subsequent international conventions and agreements, but also for legal systems of the States Parties. In a globalized world, in addition, States must commit themselves internationally to respect and guarantee the human rights of people in and beyond their borders, for several reasons: the effect of the state's own policies and actions on other countries; the impact on other countries of the way in which it participates in international institutions; provision and efficacy of development aid; and the response to rights abuses in other countries, either by criticism and public denunciation or, as a last resort, by intervention and support for intervention.

Insisting on the relevance of the state dimension, within the international community, in continuing the path initiated with the UDHR and the subsequent instruments means claiming the need for policies for the implementation of human rights and the incorporation of the human rights approach in those. In addition, it also means fighting decisively against one of the phenomena that most contributes to expanding the fierce reality of human rights violations: impunity. That fight against impunity is also a commitment to democracy and respect for the person's dignity, that idea that we saw, which is at the base of the UDHR and human rights. The words of Cassese (1991, 150), when he said that "democracy means respect for the dignity of the person; Torture means humiliation or annihilation of that dignity. For this reason, torture nests in all non-liberal states or in the authoritarian retreats of democratic state structures", are still relevant.

Beetham $(1999,89)$ is right when he argues that if we adopt a holistic vision of the UDHR, as has been proposed in this paper, it is possible to construct the parameters of democracy and establish objectives for governance systems and governance. Civil and political rights are an integral part of the basic functioning of a democratic system and social and economic rights are crucial for the effective exercise of democracy. Since 
the UDHR covers rights and indicators for democratic governance, it provides a solid foundation for the international law's definition of democracy.

In the legal dimension, since the drafting of the UDHR there has been an imbalance in the treatment of different rights, initially giving priority to the development and mechanisms of international control of civil and political rights. In the rights included in this group there are still human rights violations that have to be persecuted, but there are also rights that, from the moment of the Declaration, were recognized in a deficient manner. In that sense, freedom of movement and the right to asylum are two good examples of rights recognized in the Declaration in an insufficient manner. Thus, the Article 13 UDHR does not recognize the right of entry, nor the individual or collective immigration, just as the Article 14 UDHR does not attribute to the person being persecuted the right to obtain asylum in another State other than that of their nationality, but simply to look for it and enjoy it. This meager recognition is largely due to the number of rights related to freedom of movement and asylum, among others, the principle of non-discrimination or the right to a nationality. In addition, as was already evident at the time of drafting the Declaration, the concretion of these precepts directly affects the exercise of the sovereignty of States, mainly if such sovereignty is conceived as absolute. Therefore, in the conventional framework, and, in particular, at the national level, immigration and immigration legislation limit the right to free movement and residence for reasons such as national security, general interest, public order, health or public morals and even the situation of the labor market.

In the same vein, the right of asylum, although basically developed in the Convention on the Status of Refugees (Geneva, 1951) and its Protocol (New York, 1967), refers to a refugee concept in need of revision in order to respond to current needs. In addition, within the asylum, the basic principle of non-refoulement, is questioned before the difficulties at the time of specifying aspects as basic as the notion of a safe third country. With all this, there is insistence on the error of not recognizing the deep political dimension of this reality, denying rights (De Lucas, 2017, 65).

As regards economic, social and cultural rights, as has already been discussed, those were relegated to the background until the Vienna Declaration and the Protocol to the ICESCR. This Protocol recognized, as we pointed out, the international justiciability of the ESCR, the next step to strengthen the recognition and protection of these rights is to encourage the ratification of the Protocol; the fact that it is still very low (23 States in 2018) evidences that there is still, as in the moment of approval of the UDHR, a great reticence on the part of the States in the real comparison of both types of rights.

Other rights, such as resistance against oppression, were not accepted for inclusion in the drafting process of the UDHR, as proposed by some delegations, including Cuba, Chile, France, and the Soviet Union (Morsink, 307-312). The final report of UNESCO, derived from the consultations carried out during the drafting process of the Declaration, referred to the "right to rebellion and revolution", which does not appear in the final text either, when the Government would not comply with the fundamental principles of justice and would not respect fundamental rights "in such 
a way that could not correct such abuses by peaceful means", before which there would be the right to establish "a government that is more in conformity with justice and humanity". However, an integrated reading of the whole of the UDHR articles allows us to include this idea and maintain from the Preamble that it is "essential that human rights are protected by the rule of law", so that people do not feel compelled "to have recourse to rebellion against tyranny and oppression" taking into account that, according to the Article 29.3 of the Declaration, rights and freedoms may not be exercised in opposition to the purposes and principles of the United Nations (Del Toro 2012, 98).

Also, the limitation established by the Article 30 is important in order to establish the parameters of a democratic society. This final clause protects the rights established in the Declaration against possible attacks that may come from the State, groups of people or individuals (Burchill and Cavandoli, 2011, 58).

In the line of impulse to the rights recognized by the UDHR, Villán Durán (2018, 116-117) is correct when he points out that a current reading of the Declaration, with projection in the international community of the 21st century, also demands the aforementioned development of the Article 28, to claim what it calls the human rights of solidarity or "synthesis", departing from the essential interdependence of human rights. From this perspective, it is possible to promote the right to peace, the economic and social development of the people or the right to the environment. These last claims of rights not expressly contemplated in the UDHR (which makes sense considering the historical moment in which it was drafted) are in line with the approaches that we have already indicated that are supported by the 2030 Agenda for Sustainable Development. Human rights must be the foundation of progress towards a more just, democratic and equitable international community that can take on the challenges of peace, security, sustainable development and respect for rights from the pillars already established in the Charter of the United Nations.

Precisely, the great challenge of building the right to peace requires, in my opinion, to insist, as Cançado Trindade underlines (2010, 360), in the lack of examination of the bases for peace within each State and the role of non-state entities. Certainly, I suggest that there is a need to achieve social justice within and between nations, an "urgent need to put an end to the tendency to separate economic development from social development, macro-economic policies from the social objectives of development". Likewise, it is essential to value and promote the growth and consolidation of international jurisdictions, as well as the conferences and forums promoted by the United Nations. Precisely, one of the outstanding issues to strengthen the Declaration as a reference instrument and, above all, to guarantee the human rights recognized by it, is that of a further consolidation of the International Criminal Court, deepened in issues, such as the number of States that have ratified its Statute, and also the relevance of the fact that some of those who have the right to veto in the Security Council have not done so. In the same way, it would be interesting to debate the role assigned to individuals before said Court and the type of crimes (hitherto genocide, war and against humanity, but not, for example, terrorism) in case it would be possible to include some of the ones that are not contemplated right now. 
From the moral dimension, as a model of reference in the field of Human Rights, the Declaration is called to continue to play a relevant role. At a time like the current one, where it is no longer possible to deny the impetus of international human rights law, it is important to avoid what Habermas $(2010,120)$ calls a "soft deflation of human rights". It is a matter of avoiding a minimalism that separates human rights from their essential moral impulse, which is none other than the protection of the equal human dignity of each one. It is necessary to avoid the perspective that reduces the issue of human rights to matters strictly of international politics, in such a way that it obviates the relationship of tension within the State between universal human rights and rights of the individual citizen. This political vision is essential, as is also the legal one that erroneously strengthens the separation (and therefore exclusion) through criteria such as nationality and citizenship (as we pointed out with regard to freedom of movement and the right of asylum).

The moral basis of human rights, clearly since the UDHR, assumes that each one, as a subject of the same rights, is respected as of their human dignity. The aim is to strengthen this "new ethos of our times" (Cançado Trindade $(2010,622)$ that human rights constitute, based on the momentum created by the Declaration and the progressive development of international instruments. The UDHR cannot be considered an outdated or exceeded text; on the contrary, it was an instrument of transformation and it remains, in its 70th anniversary, an engine for the always unfinished struggle for rights.

\section{REFERENCES}

Ansuátegui Roig, Francisco Javier (1999), “La Declaración Universal de Derechos Humanos y la Ética pública”, Anuario de Filosofía del Derecho, n 16, pp. 199223.

Añón Roig, María José (2010), "Derechos sociales: cuestiones de legalidad y de legitimidad”, Anales de la Cátedra Francisco Suárez, n 44, pp. 15-41.

Alston, Philip (1990), "The Fortieth Anniversary of the Universal Declaration of Human Rights: A Time More for Reflection than for Celebration”, in Berting, Jan et al., Human Rights in a Pluralist World: Individuals and Collectivities, Westport, Meckler, pp. 1-14.

Baynes, Kenneth (2009), "Discourse ethics and the political conception of human rights”, Ethics \& Global Politics, n 2:1, pp. 1-21.

Beetham, David (1999), Democracy and Human Rights, Polity Press, Cambridge (UK).

Benhabib, Sheila (2011), Dignity in Adversity: Human Rights in Troubled Times, Polity Press, Cambridge (UK).

Brown, Gordon (ed.) (2016), The Universal Declaration of Human Rights in the 21st Century: A Living Document in a Changing World, Open Book Publishers, Cambridge, UK. 
Burchill, Richard and Cavandoli, Sofia (2011), "The contribution of the Universal Declaration of Human Rights to the promotion and protection of democracy in international law”, in Odello, Marco and Cavandoli (ed.), Emerging Areas of Human Rights in the $21^{\text {st }}$ Century. The role of the Universal Declaration of Human Rights, Routledge, Abingdon, Oxon, pp. 44-65.

Cançado Trindade, Antonio (2010), International Law for Humankind: Towards a New Jus Gentium, The Hague Academy of International Law, Martinus Nijhoff.

Cançado Trindade, Antonio, Peytrignet, Gérard y Ruiz de Santiago, Jaime (2003), Las tres vertientes de la protección internacional de los derechos de la persona humana. Derechos humanos, derecho humanitario y derecho de los refugiados, PorrúaUniversidad Iberoamericana, México.

Carrillo Salcedo, Juan Antonio (2001), Soberanía de los Estados y derechos humanos en el derecho internacional contemporáneo, Tecnos, Madrid.

Carozza, Paolo G. (2008), "Human Dignity and Judicial Interpretation of Human Rights: A Reply”, The European Journal of International Law, vol. 19, n. 5, pp. 931-944.

Cassin, René (1951), "La Déclaration Universelle et la mise en oeuvre des droits de l’homme”, Recueil des Cours de l'Académie de Droit International de La Haye, n. II, vol. 79, pp. 239-367.

Cassese, Antonio (1991), Los derechos humanos en el mundo contemporáneo, Ariel, Barcelona.

De Lucas, Javier (2008), “Las globalizaciones y los derechos”, Enrahonar 40/41, pp. 55-66.

De Lucas, Javier (2017), “Negar la política, negar sus sujetos y derechos (Las políticas migratorias y de asilo como emblemas de la necropolítica)", Cuadernos electrónicos de filosofía del derecho, n 36, pp. 64-87.

Del Toro Huerta, Maruricio Iván (2012), La Declaración Universal de Derechos Humanos: un texto multidimensional, Comisión Nacional de los Derechos Humanos, México.

Glendon, Mary Ann (2011), Un mundo nuevo. Eleanor Roosevelt y la Declaración Universal de Derechos Humanos, Fondo de Cultura Económica, Comisión de Derechos Humanos del Distrito Federal y Universidad Panamericana, México.

Habermas, Jürgen (2010), "La idea de dignidad humana y la utopía realista de los derechos humanos”, Anales de la Cátedra Francisco Suárez, nº 44, pp. 105-121.

Herrera Carbuccia, Olga (2018), “La Protección de los Derechos Humanos en la Corte Penal Internacional”, in VV. AA., $70^{\circ}$ Aniversario de la declaración universal de derechos humanos. La Protección Internacional de los Derechos Humanos en cuestión, Tirant lo Blanch, Valencia, vol. II, pp. 541-546.

Jiménez de Arechaga, Eduardo (1980), El derecho internacional contemporáneo, Tecnos, Madrid. 
Lauterpacht, Hersch (1950), International Law and Human Rights, Stevens \& Sons Lted, London.

Lepard, Brian (2010), Customary International Law. A New Theory with Practical Applications, Cambridge University Press, New York.

McCrudden, Christopher (2008), "Human Dignity and Judicial Interpretation of Human Rights”, The European Journal of International Law, vol. 19, n 4, pp. 655-724.

Morsink, Johannes (1999), The Universal Declaration of Human Rights: Origins, Drafting and Intent, University of Pennsylvania Press, Philadelphia.

Morsink, Johannes (2009), Inherent Human Rights. Philosophical Roots of the Universal Declaration, University of Pennsylvania Press, Philadelphia.

Oraá Oraá, Jaime (1999), “En torno al valor jurídico de la Declaración Universal”, in VV. AA., La Declaración Universal de Derechos Humanos en su cincuenta aniversario. Un estudio interdisciplinar, Universidad de Deusto, Bilbao, pp. 179-201.

Peces-Barba, Gregorio (1994), “La universalidad de los derechos humanos”, Doxa, n 15-16, 1994, pp. 614-615.

Pons Rafols, Xavier (1998), “La adopción de la Declaración Universal de Derechos Humanos”, in Pons Rafols, Xavier (coord.), La Declaración Universal de los Derechos Humanos. Comentario artículo por artículo, Icaria. Antrazyt, Barcelona, pp. 27-42.

Santos, Boaventura de Sousa (2004), "Hacia una concepción multicultural de los derechos humanos”, in Gómez Insa, Felipe (dir.) y Pureza, José Manuel, La protección internacional de los derechos humanos en los albores del siglo XXI, Universidad de Deusto, Bilbao, pp. 95-122.

Verdiales López, Diana M. (2018), “La importancia del enfoque de los derechos humanos en los objetivos de desarrollo del sostenible”, in Fernández Liesa, Carlos Ramón y Díaz Barrado, Carlos Miguel, Objetivos de desarrollo sostenible y derechos humanos: paz, justicia e instituciones sólidas/derechos humanos y empresas, Instituto de Estudios Internacionales y Europeos Francisco de Vitoria de la Universidad Carlos III de Madrid, nº 9, pp. 75-90.

Villán Durán, Carlos (1998), “La Declaración Universal de Derechos Humanos en la práctica desarrollada por los órganos de derechos humanos de las Naciones Unidas”, in Pons Rafols, Xavier (coord.), La Declaración Universal de los Derechos Humanos. Comentario artículo por artículo, Icaria. Antrazyt, Barcelona, pp. 73-89.

Villán Durán, Carlos (2018), “La obligatoriedad Jurídica de la Declaración Universal”, en VV. AA., $70^{\circ}$ Aniversario de la declaración universal de derechos humanos. La Protección Internacional de los Derechos Humanos en cuestión, Tirant lo Blanch, Valencia, vol. II, pp. 113-122.

Von Bernstorff, Jochen (2008), “The Changing Fortunes of the Universal Declaration of Human Rights: Genesis and Symbolic Dimensions of the Turn to Rights in 
ÁNGELES SOLANES CORELLA

International Law” European Journal of International Law, vol. 19, issue 5, pp. 903-924. 